\title{
CONCERNING CERTAIN PECULIARITIES IN THE REAL ESTATE LAWS AND PROCEEDINGS OF NEW YORK.
}

Mr. William P. Fiero, President of the Bar Association of the State of New York, in his annual address several years ago declared that the real estate laws of New York including the practice in actions and special proceedings were the most cumbrous, complicated and expensive of all the states of the Union; and those of Connecticut the simplest, and he proposed various changes and amendments to lessen the incidental time and cost. I am not aware that any of the suggested reforms have taken effect but it is certain that foreclosure sales have been made more expensive in the city of New York with no advantage to anybody except the newspapers, by changes in the mode of advertising; and mortgage loans a little more troublesome and costly to the borrowers by changes in the mechanics' lien laws and tax laws. It is doubtful, however, if New York is much worse than New Jersey, although its practice has been from time to time rendered more uncertain by changes in the Code of Procedure. The reasons for some of its peculiarities will be found in its history.

New York was originally settled by the Dutch, and in parts of Westchester and Richmond counties by French Huguenots, and being from 1609 to 1664 , and again in 1674 , under the rule of Holland, the basis of its civilization and society was not Anglo-Saxon and many of its laws, customs and institutions were derived from the civil law and the continent rather than from England. A list of many such having no English origin or analogy and differing widely from English precedent will be found in that very learned work, "The Puritan in Holland, England and America," by Douglas Campbell. Among these are several now common to various of our states, and erroneously supposed to have been brought from England.

The registration or recording of conveyances is even yet very incomplete in that country, the transfer of real estate being accompanied by delivery of the title deeds. But in New York it has been in use from the earliest times.

When the records of the realty transfers in New York county were moved to the new Hall of Records in November, I906, several 
mortgage records were found dated in $1645 .-$ (See N.Y. Herald, Nov. 28, 1906.)

Mr. Campbell shows how profoundly the character of the Pilgrim Fathers had been modified by their stay in Holland so that when they sailed from Delft Harbor they brought with them much new knowledge and many ideas changed from those which they had taken there, and the Puritan in America became a different person from the Puritan in England, and introduced laws, customs and institutions transplanted from his late temporary home. In some of the counties along the Hudson, the descendants of the Hollanders retained their old usages and language within the memory of living men. The records of the old church of Sleepy Hollow at Tarrytown were kept exclusively in Dutch until 1785 when the Rev. Stephen Van Voorhis soon after his coming instituted the use of English in the baptismal service and gave such mortal offense to some of his congregation that his stay was shortened by the opposition so created.

After the English occupation in 1664, when New Netherlands became the royal province of New York, the English common law superseded the Dutch, and except in 1674 , when it lay dormant, has remained the basis of our jurisprudence to this day mixed with and modified by a host of old customs and of statutes ancient and modern.

Another change took place at the Revolution. The common law of England as it was before our independence is declared to be the law of the State of New York, certain statutes, however, of Elizabeth as to charitable uses being decided not to be a part of the common law.

But from that time the statutes and the decisions of courts continually widened the differences between the laws and the practice of the various states and they drifted farther from their early state and from each other.

Even in the earliest days, however, the student and the searcher of records will notice a radical difference between the New England and the Middle States. The town system in the former is the basis of much of their government and taxation and of their law and records. The town is their political unit and government by the town meeting is the institution said to have been so much admired by Thomas Jefferson. There is little trace of any such thing in New York. The county is the unit. The town supervisors meet and direct the affairs of the county as a board. The poor are housed not in town farms and houses, but in county houses. The courts sit and all records are kept at the county seats. The probate judges 
are county judges or surrogates of counties. The records of births, deaths and marriages, if kept at all, are there or with the boards of health of cities and villages which may or may not coincide with the boundaries of the town.

To the genealogist especially this is a source of vexation for he finds nothing like the Connecticut town clerks' and probate records while trying to trace family lines up or down.

The Revised Statutes of $1827-8$ made great changes in the laws of real estate, specially as regards uses and trusts and in wills. Among other things it was no longer necessary to use the word "heirs" in order to create a fee.

Land can only be entailed for two lives in being at the death of the testator or the commencement of the trust and twenty-one years after instead of any number of lives as in England, Connecticut and others of our states. Many succeeding revisions of the statutes have followed. Seals are no longer necessary reversing the old common law which required a seal only and not a signature.

Next came the new Constitution of 1846 and the Judiciary Act of 1847. The judges became elective for varying terms of years instead of being appointed for life or during good behavior. This is supposed by the best thinkers to have been a mistaken policy and to have lowered the standard of the judiciary making them more dependent on political leaders and generally drawn from a lower rank of lawyers than formerly.

The Court of Chancery was abolished and all legal and equitable jurisdiction united in the Supreme Court and all suits which might be pending in Chancery July I, I847, were transferred to it.

This was immediately followed by the Code of Procedure with its sweeping changes revolutionizing the old court practice which hitherto had been much the same in all the older states that inherited English forms of actions, among other things the distinction between actions at law and suits in equity was abolished as well as the different forms of those actions. By the time this code had been amended as perfectly as its nature would admit, and thoroughly adjudicated and understood the Code of Civil Procedure was substituted for it in 1877 and with its yearly amendments has made great and sometimes radical changes in practice and pleadings and occasionally in rights as well as in remedies.

The real estate laws of 1896 and their amendments have followed and so far close up this chapter.

All these make up "a mighty maze and all without a plan." The result has been an uncertainty in regard to titles, encumbrances and procedure in real estate actions so great that one distinguished firm 
in New York city frequently advised their clients in any large purchase to decline taking title until a suit for specific performance had been carried to the Court of Appeals so that they should have an adjudicated title and a fair certainty that they could thereafter borrow on it or sell.

Some remaks on a few of the more prominent and peculiar actions and proceedings affecting real estate as they have developed under the laws above mentioned may be of interest to students in a state whose history and laws differ so widely from ours, and I have chosen for this purpose

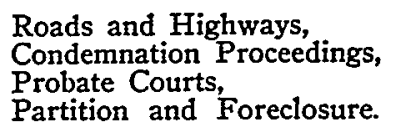

The idea of a code is attractive. To codify the result of many years' enactments and decisions into a few brief sentences so that every student can see the whole subject at a glance seemed to be a great step in the direction of certainty, simplicity and economy. Every right, every remedy should be plain and definite. When the Code of Procedure was adopted, its author, David Dudley Field, said with Horace: "Exegi monumentum aere perennius, regalique situ pyramidum altius."

But it proved to be an iridescent dream. The old law and practice had become well settled, but the attempt to embody them in new words made new misunderstandings and new litigation. Then the mania for amendments began.

That great lawyer, James C. Carter, said: "The American people are afflicted with a passion for legislation amounting almost to a disease." For sixty years every session of the legislature has brought forth a crop, often to serve some private end. The largest part of the reports have been devoted to decisions on questions raised by the code. Only one state has been worse code-ridden than ours. An old justice of the Supreme Court of the United States once told the author that when a question came before them involving any section of the California code, it was necessary to read the whole work through to see if some other section did not modify or repeal it.

It is not in the scope of this article to go deeply into the subject but merely to mention a few of the actions and proceedings which seem most to need reform and briefly refer to a few remarkable cases which have arisen under them.

\section{First of Highways.}

The question of the respective private and public rights in the roads and highways has been strenuously litigated and the decisions 
are most conflicting. As cities grew and street railways, steam railways and other corporations were chartered and began to use the streets and roads, the subject became of importance and the courts have held that they came under three entirely different kinds of law. There still exist some of the ancient roads opened under the Dutch government. These came under the civil law and belonged absolutely to the sovereign and his successors. The title to highways opened under the ordinary common law is vested in the owners of land lying on each side subject to the easement of the public to pass over, but not to the use of corporations, like railways, etc., and this extends to some of the older streets of cities. As to the newer streets the fee is generally in the corporation but strictly in trust for the people. Still different principles have been applied in cases of trespass of elevated railways, of highways or private roads closed, and of the conflicting rights of land owners and municipalities. Whoever will take a New York Digest under the title of "Highways" can soon find a mass of contradictory decisions full of such nice differences and hair-splitting distinctions as would delight a school man of the Middle Ages.

In this connection the matter of Apthorp's lane is one of the most curious. It is reported in Mott v. Mott, $68 \mathrm{~N}$. Y. Reports 246 and 8 th Hun's Reports 474 decided in 1877 , and illustrates the uncertain varying decisions of our courts as applied to the meaning of like words under different surrounding conditions, and also the beauties of our statute of limitations under which the quiet possession of a life time may give no good title.

The executors of Dr. Valentine Mott had in 1874 sold a number of lots in the city of New York to Mr. Cossitt who refused to complete his purchase because an old lane twenty feet wide ran diagonally across them. The title had come from the heirs of Charles W. Apthorp who died in I797 owning a farm through which ran this lane from Central Park westward. The piece north of the lane was sold by his heirs in 1799 and the piece on the south in 1800 . The deeds ran to the side of the lane and then along it and with the privilege at all times of using the same, etc.

By the commissioner's map in 1809 the city was laid out into rectangular blocks and the old roads and lanes legally closed. Dr. Mott had bought the land on both sides in 1833 and 1834 and supposing that he owned the lane had closed it up by locked gates. The special and general terms of the Supreme Court both declared his title to be good but the Court of Appeals, while admitting that the terms of the old deed in 1799 would convey the fee of a highway decided that in case of a lane the probable intent had been only to 
grant the right of user. That the fee was still in the heirs of Apthorp, but yet that Dr. Mott's estate or assignees had the entire right to use and enjoy the land. Now in ordinary cases adverse possession of twenty years under claim of title would have been sufficient. But infants and married women were excepted under the statute of limitations and it chanced that one of Apthorp's daughters marrying under the age of twenty-one years was still alive, and so for seventy-four years the statute had not begun to bar her rights.

$U_{p}$ to this day more than half of the lots in a fine block are poorly improved and lessened in value because a strip twenty feet wide crosses them which the owners under this ruling have the sole right to use and occupy but do not own.

The actions thought by Mr. Fiero to be most in need of reform were partitions and foreclosures, but I place at the head- .

CondEMNATIONS.

First and most profitable to those engaged in them are proceedings to condemn real estate for public uses. They stand pre-emiment for the same reason that "Satan, exalted, sat in his infernal assembly."

They are conducted before three commissioners appointed by the Supreme Court to take proof of title and incumbrances, to hear the claims of owners and to report to the court upon the value to be paid for the land. The court then hears and decides on any objections and fixes their compensation and expenses. It is not only that the proceedings are often believed to be corrupt but that both the legislature and the courts have united to make them as extravagantly costly as possible. The commissioners sit as often as they choose. Any member who does not actually attend has his appearance noted and is constructively present, and the length of their day may be anything which can be appreciably measured by the clock. Among the pieces of patronage most valued by some judges are the appointments of their favorites and political friends to be commissioners in condemnation proceedings. Their fees are practically unlimited being in the discretion of the court which generally grants whatever is asked. A good example is the matter of Hamilton Park which the Controller of New York is now trying to investigate. The city has just paid more than $\$ 151,000.00$ in condemnation proceedings for a small triangle of land which the owner had long offered for sale at $\$ 80,000$. This is not a glaring instance. One part of the law which vests title to land in the city when proceedings are begun $I$ believe to be unconstitutional and a taking of private property for public use without compensation. Agreeing to fix a 
price for property to be paid at some far future time if the town or city is then able to do it is not the equivalent of cash.

Of Probate and Surrogates' Courts.

There is nothing more peculiar to New York than its probate courts and proceedings.

Under the Dutch government the jurisdiction over estates was governed by the Roman law and the custom of Amsterdam and exercised by the Colonial Council and the Court of Burgomasters. After the English occupations in I 664 it was transferred to the mayor's court and wills and inventories were recorded with the secretary of the province in New York city. After 1689 all probates and inventories were taken by the governor-general or the secretary as his deputy who held what was known as the Prerogative Court. The surrogate at first was only the governor's delegate and the governor's approval of a will recited that "to me and not to any inferior officer whatsoever pertains the granting of probate and administration."

Since the Revolution, wills have been proved and recorded in the counties where the testator resided. The Prerogative Court of the Secretary kept no records so far as could be discovered. It was abolished at the Revolution. In many counties the surrogate's office was vested in the old Common Pleas, now the County Judges; in many others he is a separate officer. Since $x 746$ his powers have continually increased till now he is an officer altogether unique, being a court of record and uniting all the powers of surrogate's, probate and orphans' courts of other states as well as many of the powers of the higher courts of equity. He admits wills to probate, grants administration, tries the cases of contested wills and has concurrent jurisdiction with the Supreme Court and in some cases exclusive jurisdiction over all matters of the appointment, removal and acts, and accountings of administrators, executors, trustees and guardians.

Up to the year I880 the proceedings and the law in his court were much like those of the English ecclesiastical courts. His attorneys were called proctors; the process issued is not a summons but a citation and the fees and allowances were until recently unlimited. It was the custom in contests over probate, etc., to grant allowances impartially to the victors and the vanquished. Sometimes they amounted to half the property. It became a by-word that a rich man did not dare to die in New York, for someone would contest his will to get huge allowances. The practice was even more desirable than that of David Copperfield's little clique of proctors. 
At last the legislature put an end to the scandal; only the prevailing party receives costs and allowances and they are all strictly limited in amount.

The probate of a will or the grant of administration is not a simple matter. The husband or wife, all heirs and next of kin, all persons in being who would take any interest in the estate by the will, must be cited. If they reside in the state they must be personally served and if non-residents an elaborate and technical mode of advertising must be had and the will cannot be sworn to and prove itself as in Connecticut.

The proof of an uncontested will is almost equivalent to a trial. Inventories and accountings are equally formal and no decree is binding on a person omitted or improperly served. But with all this the surrogate lacks one of the most essential powers. An administrator in Connecticut desiring to sell real estate has a simple mode of petition to the probate judge for an order of sale. But neither the surrogate nor any court in the state of New York can grant such relief. The only power is to order a sale on proof that the personal property is insufficient to pay the debts of the deceased and this proceeding is so technical, the uncertainty of titles under it so great that practically it merely prevents any sale by the heirs during three years.

A curious situation arises where an executor not specially authorized under the will buys real property with funds of the estate. Some contend that he can never sell it again; others that he has by his wrongful act taken it, not as an executor, but individually, or else that by the principle of equitable conversion the land remains money, and in either case he can give a good title, as, where he takes property in foreclosure brought by himself.

It has not yet been decided by the Court of Appeals and remains as doubtful a question as that which puzzled the lone juryman told of by Mr. Albert Matthews, who being accepted on a trial for lack of any more jurymen, heard the evidence, the learned speeches of counsel, and the judge's charge, and after a long deliberation reported to the court "that the jury could not agree."

It follows that the action of partition is more necessary and more frequently resorted to in New York than elsewhere as it is so often the only way in which land belonging to tenants in common under wills, trust deeds, or as heirs of intestates can be sold. Even a special act of the legislature will not avail as was decided by the Court of Appeals in I873 in the case of Brevoort v. Grace, 53 N. Y. Reports, page 245 . 
Leffert Lefferts owned eighty-five acres in Brooklyn and died in 1847 , leaving a will by which he devised one-half the income of his farm to his wife during her widowhood and the residue to his daughter, Mrs. Brevoort, for life,-the remainder of the farm to her issue in fee. In case she left no issue her surviving, then such remainder to such children of his brother John as might be living at the time of testator's death. The farm was in the city of Brooklyn, the taxes and assessments were far above the income; parts of it were sold for taxes and the devisees were fast being ruined. In 1872 the legislature by special law authorized a sale by order of the Supreme Court on petition of Mrs. Brevoort, her husband and issue and on appointment of guardians for all minor heirs and the investment of the proceeds for those who might be entitled to the income or the land. She was then fifty-one years old, her only son over twenty-one and the descendants of John were about thirty in number.

The petition was made and an order of the Supreme Court with all the requirements of the law, and a sale took place. The purchaser refused to accept the deed, the Supreme Court decided the title to be good, but the Court of Appeals held that the legislature had no power to cut off the contingent remainders of the adults and rejected the title.

Mrs. Brevoort then began action for partition and made as parties every person who by any contingency present or future might have or claim any interest or lien in the land. This, too, was litigated to the Court of Appeals which finally in 1877 confirmed the sale, but only on condition that the proceeds were invested in trust to answer to any future rights of persons living or yet unborn. See Brevoort v. Brevoort, 70 N. Y. 36.

\section{Partition.}

The action of partition is the most difficult, complicated and expensive of all real estate actions. It is substantially the old Chancery suit modified by the Revised Statutes and the Code. It may be brought by any tenant in common and may ask for actual partition or sale and may incidentally contest the validity of any will involving the title. The parties as directed by Section $153^{8}$ of the Code must be "Every person who by any contingency contained in a devise or grant or otherwise is or may become entitled to a beneficial interest in an undivided share therein." If infants are concerned it must include all lands owned by the parties in common and if a sale is wanted it must also appear that actual division cannot be made without great injury to all interests and every person having any lien general or specific must be made defendant. 
Very elaborate provisions are made for absent or unknown or infant defendants which, being statutory, must be exactly followed and cannot be amended by the court. When the case is ready for trial a referee is appointed to take proof of the facts and of the title. His fees and expenses are unlimited. On his report a decree of sale is made and another referee appointed to make sale, after which another decree follows confirming the sale and distributing the proceeds. The question of who are the necessary defendants has caused more litigation over this action than all others. In the good old days some thirty years ago the judges assumed the rights of the English Court of Chancery over a fund in court and granted allowances at discretion to the attorneys. I remember one case where property belonging to some infant children was sold for about $\$ 6,000$ -and the costs and allowances were over $\$ 4,000$. But the Court of Appeals finally decided that no such authority had ever existed in our courts. The total allowances to attorneys cannot now exceed $\$ 4,000$. The other expenses of course are unlimited.

Looked at from the proper point of view the action of Partition, like the famous suit of Jarndyce and Jarndyce, is a consistent and beautiful whole-a monument of legal lore, exhibiting sometimes every expedient and every cheerful fiction of practice.

But as a practical means for selling and dividing estates it is an unscientific, clumsy and profligate mode of devouring widows' and orphans' houses.

\section{ForeCLOSURE.}

A mortgage is an anomalous instrument. It is a conveyance and any deed with a defeasance, even a verbal one, is a mortgage, but a mortgage is not a conditional deed. It is merely a collateral security, and a decree foreclosing it is only an additional security for the debt and expires under the statute of limitations. So far have we departed from the oppressive old common law which gives interest to Scott's "Fortunes of Nigel."

In many of the states it is a deed of trust and foreclosure on default is a simple matter of advertisement and public sale by the trustee leaving any other lienors or creditors to assert their claims on the surplus moneys. In New York the statutory foreclosure under the power in the instrument is full of technicalities and seldom used, so the ordinary resort is to the action in equity. Under this the sheriff or a referee is finally appointed to sell the land at auction and for any deficiency the plaintiff has personal judgment against the mortgagor. The decree "is a bar against each party to the action who was duly summoned, and every person claiming 
under a party by title accruing after filing of notice of pendency of action" (Code of Civil Procedure, Section I632).

It follows that if any person having any estate or claim, legal or equitable, is omitted from any of the proceedings he is not affected, and may redeem till barred by limitation of time. How long this may be was shown in the case of Giles v. Solomon, to Abbott Practice Reports, new series, page 197. The plaintiff's father died in 1840 , leaving a widow and six children. In January, 1841, a foreclosure was brought against their property, making them all parties. Two days before final decree the plaintiff, a posthumous child, was born and not made defendant. It was held that he could redeem the property in 1866 , twenty-five years after the sale. Besides an unscrupulous defendant can delay the action for years by some trivial defense and a series of motions and appeals so that a foreclosure may at times become a formidable operation.

There are several radical defects common to all real estate actions alike. The judgment or decree is conclusive only on defendants who were properly summoned and persons claiming under them. Now whoever searches a title in New York will find twenty or more liens and incumbrances filed or recorded in many different public offices. Half of these, such as judgments and various kinds of bonds, etc., are general liens, entered only against name and affecting all the property of the individual whose identity sometimes remains an unknown quantity.

Besides the courts have held that the index is no part of the record which is equally effectual, although omitted from the index.

There are also facts of fanily history not of record: e. g., marriage, descent, infancy, etc., which often baffle all inquiry. The wife's dower in New York attaches to all real estate of which the husband is seized at any time after marriage and the laws on the subject of marriage are loose, answering closely to Wilkie Collins's rather sarcastic description of the law of Scotland. It is a civil contract with no need of form, ceremony or witnesses. Any woman is presumed to be the wife of any man against whose estate she makes claim. She may assert, as one woman did, that the agreement was made on a ship in the English Channel, or in any other place where it is not actually void by local law, and they who oppose her must prove a negative.

And when all possible parties have been brought in there remain the requirements of the statute in regard to infants, unknown or absentee defendants, which must be strictly followed or the court has no jurisdiction. As no proceding short of the final decree actually entered, is binding on any person upon whom a right or title 
devolves by operation of law, it will be seen that during a long action there is an excellent opportunity for new defendants to come into being by birth, marriage, death or bankruptcy.

The law on this point was finally settled by one of the most remarkable and bitterly fought ejectment suits. Isaac Requa died leaving a farm at Tarrytown on the Hudson, and in 1826 a suit for partition was begun by his heirs in the Court of Chancery. Just before final judgment, when all proceedings against all defendants had been taken "pro confesso," one of them, a brother of deceased, died leaving infant children. They were not made parties, but the order of sale was made and the sale made and confirmed Nov. 6, 1826. In October, 1827, the court ordered the action to stand revived against the infants and the proceedings confirmed, and on consent of their solicitor, part of the proceeds were invested as a dower fund for their mother and the rest was paid over to and for them.

In 1844 several of them brought ejectment against the purchasers claiming that the judgment was not binding upon them because they had not been brought in as original parties and allowed to defend from the beginning. They were defeated but in 1857 the Court of Appeals ordered a new trial. In March, 1860, they were again defeated. Again in 186I the Court of Appeals ordered a third trial which was had in March, 1862 , and in 1863 the Court of Appeals gave final judgment in their favor and the point was settled that a person on whom a right or title devolves by operation of law must be made a party and the action proceed against him "de novo and $a b$ origine." The suit which the plaintiffs once offered to settle for $\$ 500$ and were refused, finally ruined two successive owners of the land and cost another $\$ 20,000$, and ran its course for twenty years. See Requa v. Holmes, I6 N. Y. I93, decided, I857; Requa v. Holmcs, 26 N. Y., decided 1863.

Another great defect is the lack of any record whose recital should be conclusive evidence of the various proceedings in the action. The so-called judgment roll is merely a bundle of detached papers tied up with tape. The whole jurisdiction of the court depends on a mass of separate appearances, orders and affidavits of service, mailing and publication. By time, carelessness or design, some of these may be lost and with them goes all proof of jurisdiction.

There are always persons hunting up flaws or omissions and many are the titles clouded thereby. It is no wonder that the cost and uncertainty of real estate searching have caused the rise of title 
companies which have almost supplanted the individual conveyancers.

Two simple changes in the law would at once do away with much of the searcher's labor and the present cost and delay of actions. The first is to abolish all general liens. Let judgments affect no land until it is taken in execution. The second is let there be dower only in land which has not been sold during the husband's life, and require the claim to be promptly made. But the only complete reform is the Torrens system of governmental registration of titles now in force in Australia, so that the evidences of ownership may pass from hand to hand as simply and safely as do those of personal property.

Pierre W. Wildey. 